\title{
DETEKSI PENCEMARAN BAKTERI Salmonella Sp. PADA UDANG PUTIH (Penaeus merguiensis) SEGAR DI PASAR TRADISIONAL KOTAMADYA SURABAYA
}

\section{POLLUTION DETECTION OF Salmonella sp. TO FRESH WHITE SHRIMP (Penaeus merguiensis) AT TRADITIONAL MARKET OF SURABAYA RESIDENCE}

\author{
Hasutji Endah Narumi ${ }^{1}$, Zuhriansyah ${ }^{2}$ dan Imam Mustofa ${ }^{2}$. \\ ${ }^{1}$ Fakultas Kedokteran Hewan Universitas Airlangga \\ Kampus C Mulyorejo - Surabaya, 60115 Telp. 031-5992785 \\ ${ }^{2}$ PPDH Fakultas Kedokteran Hewan Unair \\ Kampus C Mulyorejo - Surabaya, 60115 Telp. 031-5992785
}

\begin{abstract}
The aim of this study were to know the level of contamination againts Salmonella sp. bacteria in fresh white shrimp at the traditional market in surabaya. The fresh white shirmp were collect from 5 areas in Surabaya (East, South, Center, North and West). Total samples were 25 (five samples for each area) dan each sample were weight 100 gram. Sample from each area were using mortar and making for a suspention to take the isolate. More over using SPSS medium for enriched them further more were observed under the microscope also were test for the biochemistry characteristics.

Data from the enrichment for Salmonella sp. bacteria were descriptive analyze and to know the level of contaminations we used chi-square : the result of this study were indicate that the fresh white shrimp at the traditional market in Surabaya were contaminated with Salmonella sp. bacteria, but they didn't show the significant different at the contaminant fish levels $(p>0,05)$.
\end{abstract}

Keywords : Salmonella sp., Penaeus merguiensis, traditional market

\section{Pendahuluan}

Salmonellosis merupakan salah satu penyakit yang dapat dipindahkan melalui makanan, terutama makanan yang mengalami kesalahan dalam penanganan. Keadaan ini akan memberikan kesempatan pada mikroorganisme penyebab untuk tumbuh dan berpindah ke manusia pada waktu memakannya. Pada tahun terakhir ini, peranan Salmonella sebagai agen penyebab Food Borne Disease menjadi perhatian dunia, karena peningkatan kejadian Salmonellosis baik pada hewan maupun manusia (Prawesthirini, 1990). Di beberapa negara, ikan dan air dapat merupakan sarana penyebaran Salmonella (WHO, 1976).

Udang yang terdapat di pasaran sebagian besar terdiri dari udang laut yang salah satu diantaranya adalah udang putih. Udang ini banyak dijumpai di pasar-pasar tradisional tetapi sangat jarang pada pasar-pasar swalayan yang ada di Surabaya. Tambak dan lingkungannya dimana udang dipelihara saat ini tidak menutup kemungkinan merupakan sarana pencemaran Salmonella sp.,air dimana udang hidup didalamnya merupakan sebagai salah satu faktor pencemaran. Proses pemasaran di pasar tradisional yang kurang higienis merupakan faktor lain penyebab Salmonellosis.

$$
\text { Penyakit asal makanan yang }
$$

disebabkan oleh mikroorganisme dan dipindah sebarkan melalui makanan terjadi menurut salah satu dari dua mekanisme, yaitu mikroorganisme yang terdapat dalam makanan menginfeksi inang sehingga menyebabkan penyakit asal makanan dan atau mikroorganisme mengeluarkan eksotoksin dalam makanan dan menyebabkan mabuk makanan atau keracunan makanan bagi yang memakannya (Pelczar dan Chan, 1988). Pencemaran Salmonella sp. pada udang putih khususnya masih belum banyak di laporkan.

Udang putih yang beredar dipasaran tidak menutup kemungkinan tercemar oleh bakteri diantaranya Salmonella sp. Sumber dari pencemaran ini sangat bermacam-macam yang salah satu diantaranya adalah kesalahan proses penanganan, baik mulai dari asal udang diproduksi sampai pada pemasarannya. Bakteri Salmonella sp. merupakan bakteri penyebab Salmonellosis yang menyerang hewan dan manusia. Penyakit ini merupakan penyakit menular yang dapat ditularkan melalui makanan juga bersifat zoonosis (Anonimus, 1994). Penularan kuman Salmonella dapat melalui 
makanan dan minuman yang tercemar serta kontak langsung maupun tidak langsung (Merchant dan Packer. 1967). Menurut Pelczar dan Reid (1958) bakteri Salmonella sp. merupakan bakteri yang sangat patogen pada manusia yang dapat menyebabkan penyakit perut (diare). Kurang higienisnya udang segar di pasar-pasar tradisional mendorong timbulnya pencemaran Salmonella sp.

Di seluruh dunia Salmonella merupakan masalah yang besar, sebagian infeksi kuman ini berasal dari makanan. Walaupun demikian sekarang ini masih terbatasnya studi di laboratorium, kurangnya penyelidikan Salmonellosis di negara berkembang membuat sulit untuk ditafsirkan pentingnya penyakit zoonosis ini (WHO, 1985). Penjangkitan Salmonellosis karena makanan bersifat eksplosif dan ini sangat sering terjadi karena manusia kurang memperhatikannya (Pelczar dan Chan,1988).

Semua aktivitas yang berhubungan dengan bahan makanan harus memenuhi persyaratan kesehatan masyarakat agar bahan pangan tersebut tetap sehat dan dapat dikonsumsi oleh manusia. Dalam hal ini pemerintah berkewajiban mengadakan pengawasan didalam pelaksanaannya serta dilakukan pengujian untuk mengetahui bahanbahan tersebut memenuhi persyaratan dari kesehatan. Sesuai keputusan Direktorat Jenderal Pengawasan Obat dan Makanan Nomor : 03726/B/SK/VII/89 udang tidak boleh tercemar Salmonella sp. Dewasa ini peranan dokter hewan dalam kasus Salmonellosis dan penyakit Zoonosis food disease lainnya sangat diperlukan terutama, dalam mengontrol sanitasi, kualitas makanan dan produk makanan asal hewan, pencegahan, menjamin kondisi higienis selama pemasaran, serta mencegah pembusukan yang berasal dari udara terbuka di tempat pemasaran.

\section{Materi dan Metode Penelitian}

Bahan berupa udang putih segar yang diambil dari beberapa pasar di Kotamadya Surabaya yang terdiri atas lima wilayah yaitu wilayah Surabaya Timur, Surabaya Selatan, Surabaya Pusat, Surabaya Utara dan Surabaya Barat. Medium yang digunakan Salmonella Shigella Agar (SSA) produksi dari Difco Laboratories Detroit, USA. Sedangkan medium yang dipakai dalam uji biokimiawi adalah Triple Sugar Iron Agar (TSIA), Indol, Urease, Citrat dan uji fermentasi gula-gula (glukosa, laktosa, maltosa, mannitol dan sukrosa). Bahan lain yang menunjang penelitian ini adalah larutan $\mathrm{NaCL}$ fisiologis $0,9 \%$, alkohol $70 \%$, alkohol 96\%, aquades streril dan bahan pewarnaan Gram.

Sampel udang putih segar sebanyak 25 sampel yang diambil pada pukul $06.00-09.00$ WIB dari beberapa pasar di Kotamadya Surabaya dimana setiap wilayah diambil 5 sampel dan setiap sampel sebesar 100 gram. Setiap sampel dari masing-masing wilayah pengambilan dimasukkan ke kantong plastik untuk dibawa ke Laboratorium Bakteriologi dan Mikologi Fakultas Kedokteran Hewan Universitas Airlangga Surabaya.

Masing-masing sampel dimasukkan ke cawan petri steril, kemudian setiap sampel digerus sampai halus selanjutnya masingmasing sampel hasil gerusan diambil 25 gram dan dibuat suspensi dengan penambahan $\mathrm{NaCL}$ fisiologis $0,9 \%$ di dalam gelas ukur, selanjutnya dihomogenisasi dengan menggunakan blender selama lebih kurang 2 menit.

Isolasi bakteri dilakukan dengan cara mengambil isolat dari suspensi dengan menggunakan ose steril dan dipupuk pada medium SSA dengan cara streak pada permukaan medium kemudian diinkubasi pada suhu $37^{\circ} \mathrm{C}$ selama 24 jam. Identifikasi bakteri dilakukan pada koloni terduga yang berbentuk bening halus yang datar dan selanjutnya dilakukan pemeriksaan mikroskopis dengan menggunakan pewarnaan Gram. Pemurnian bakteri dilakukan dengan cara mengambil beberapa koloni yang dicurigai Salmonella $s p$ dengan ose steril kemudian dipupuk dengan medium yang sesuai untuk pertumbuhan bakteri yaitu medium SSA. Cara pemupukan sama seperti pada isolasi bakteri, kemudian diinkubasi pada suhu $37^{\circ} \mathrm{C}$ selama 24 jam. Koloni yang tumbuh setelah diinkubasi hampir selalu berbentuk sirkuler dengan permukaan halus dan bening, berdiameter 2-3 mm (Jang et al, 1976). Setelah dapat dipastikan bahwa koloni bakteri yang tumbuh adalah koloni yang murni, kemudian dilanjutkan dengan uji biokimiawi yang meliputi uji pada medium TSIA, Indol, Citrat, Urease dan fermentasi gulagula.

Peubah yang dapat diamati pada penelitian ini adalah : Keberadaan Salmonella sp. pada udang putih segar dan Tingkat pencemaran Salmonella sp. pada lima wilayah Kotamadya Surabaya.

Data yang terkumpul disajikan dalam bentuk deskriptif yaitu menghitung persentase udang putih segar yang tercemar dan kemudian ditampilkan dalam tabel dan diagram batang, kemudian untuk mengetahui perbedaan tingkat pencemaran Salmonella sp. pada udang putih segar yang dipasarkan pada lima wilayah di Kotamadya Surabaya digunakan uji Chi-kuadrat 
(Sudjana, 1992).

\section{Hasil dan Pembahasan}

Hasil penelitian dengan cara uji bakteriologis menunjukkan bahwa udang putih segar yang dipasarkan di pasar tradisional di wilayah Kotamadya Surabaya positif oleh bakteri Salmonella sp., dapat ditunjukkan pada medium Salmonella Shigella Agar (SSA) terdapat koloni halus bening dan merata pada permukaan medium, pada sebagian medium terdapat warna hitam pada koloni tersebut.

Hasil pengujian secara biokimiawi pencemaran Salmonella sp. pada udang putih yang dipasarkan di pasar tradisional di wilayah Kotamadya Surabaya disajikan dalam keterangan lainnya. Sedangkan jumlah, sampel yang positif tercemar Salmonella sp. disajikan dalam Tabel 1.
Persentase udang putih segar yang tercemar Salmonella sp. yang dipasarkan di pasar tradisional di wilayah Kotamadya Surabaya disajikan dalam Tabel 2.

Hasil penelitian yang telah dilakukan, perbedaan persentase tingkat pencemaran Salmonella sp. pada udang putih segar yang dipasarkan di pasar tradisional antar wilayah Kotamadya Surabaya diuji dengan menggunakan Chi-Kuadrat. Berikut ini disajikan hasil pengujian tingkat pencemaran Salmonella sp. pada udang putih segar yang dipasarkan di pasar tradisional antar wilayah Kotamadya Surabaya pada Tabel 3.

Hasil pengujian ini menunjukkan $\mathrm{X}^{2}$ hitung $=5,67$ dan $X^{2}$ tabel $=9,49$ dengan menggunakan taraf nyata $=0,05 \mathrm{dan} d \mathrm{k}=4$, berarti diperoleh $\mathrm{X}^{2}$ hitung lebih kecil dari $\mathrm{X}^{2}$

Tabel 1. Hasil pemeriksaan tingkat pencemaran Salmonella sp. pada udang putih segar yang dipasarkan di pasar tradisional di wilayah Kotamadya Surabaya

\begin{tabular}{|c|c|c|c|c|c|}
\hline \multirow{2}{*}{$\begin{array}{c}\text { No. } \\
\text { Sampel }\end{array}$} & \multicolumn{5}{|c|}{ Salmonella sp. } \\
\cline { 2 - 6 } & Timur & Selatan & Pusat & Utara & Barat \\
\hline 1 & + & + & + & - & - \\
2 & + & + & - & - & - \\
3 & - & - & + & - & - \\
4 & - & + & - & + & - \\
5 & - & - & - & - & + \\
\hline
\end{tabular}

Keterangan : $\quad$ Tanda $+=$ positif Salmonella $\mathrm{sp}$

Tanda - = negatif Salmonella $\mathrm{sp}$.

Tabel 2. Data deskriptif pencemaran Salmonella sp. pada udang putih segar yang dipasarkan di pasar tradisional di wiiayah Kotamadya Surabaya

\begin{tabular}{|c|c|c|c|c|c|}
\hline \multirow{2}{*}{ Wilayah } & \multirow{2}{*}{ Jumlah Sampel } & \multicolumn{2}{|c|}{ Positif } & \multicolumn{2}{c|}{ Negatif } \\
\cline { 2 - 6 } & & Jumlah sampel & $\%$ & Jumlah sampel & $\%$ \\
\hline Timur & 5 & 2 & 8 & 3 & 12 \\
Selatan & 5 & 3 & 12 & 2 & 8 \\
Pusat & 5 & 2 & 8 & 3 & 12 \\
Utara & 5 & 1 & 4 & 4 & 16 \\
Barat & 5 & 1 & 4 & 4 & 16 \\
\hline
\end{tabular}

Tabel 3. Hasil pengujian pencemaran Salmonella sp. pada udang putih segar yang dipasarkan di pasar tradisional di wilayah Kotamadya Surabaya dengan menggunakan uji Chi-Kuadrat.

\begin{tabular}{|c|c|c|c|c|c|c|}
\hline \multirow{2}{*}{ Salmonella sp. } & \multicolumn{5}{|c|}{ Wilayah Surabaya } & \multirow{2}{*}{ Jumlah } \\
\cline { 2 - 6 } & Timur & Selatan & Pusat & Utara & Barat & \\
\hline+ & 2 & 3 & 2 & 1 & 1 & 9 \\
- & 3 & 2 & 3 & 4 & 4 & 16 \\
\hline Jumlah & 5 & 5 & 5 & 5 & 5 & 25 \\
\hline
\end{tabular}

Keterangan : $\quad$ Tanda $+=$ positif Salmonella $\mathrm{sp}$.

Tanda - = negatif Salmonella $\mathrm{sp}$. 
tabel. Hasil ini dapat diartikan bahwa udang putih segar yang dipasarkan di pasar tradisional positif tercemar Salmonella sp. tetapi tidak menunjukkan perbedaan yang nyata. Penghitungan lengkap pada pengujian ini disajikan dalam keterangan lainnya.

Penelitian yang telah dilakukan menunjukkan hasil analisis udang putih segar yang dipasarkan di pasar tradisional di lima wilayah Kotamadya Surabaya 36\% tercemar oleh Salmonella sp. dengan rincian : Surabaya Selatan 12\%, Surabaya Timur dan Surabaya Pusat $8 \%$ dan Surabaya Utara dan Barat $4 \%$. Dari data di atas menunjukkan bahwa wilayah Surabaya Selatan merupakan wilayah yang paling tinggi tingkat pencemaran Salmonella sp. pada udang putih segar yang dipasarkan. Keadaan ini disebabkan keadaan pasar tradisional di wilayah tersebut terlalu padat sehingga sering terjadi pencampuran udang putih segar dengan barang-barang dagangan lainnya. Keadaan ini ditunjang oleh keadaan pasar yang terlalu kotor dan tata pasar yang masih sederhana dan semrawut. Thomas (1973) mengatakan lalat dan debu merupakan salah satu dari surnber infeksi bakteri.

Wilayah Surabaya Utara dan Surabaya Barat merupakan wilayah yang terendah tingkat pencemarannya. Sebenarnya karakteristik pasar tersebut tidak jauh berbeda dengan pasar wilayah lainnya, tetapi pasar tersebut relatif lebih bersih dan teratur tatalaksananya.

Buckle et al. (1979) menyebutkan kondisi pasar yang masih sederhana sanitasi lingkungan yang buruk, serta tatalaksana pamasaran yang tidak baik mendukung peningkatan kontaminasi dan perkembangbiakan bakteri.

Pencemaran juga bisa terjadi dari sumber asal dari tambak atau sumber lainnya dimana udang berkembang biak. Pencemaran disini bisa berasal dari pencemaran zat cair ataupun zat padat yang masuk ke dalam air tambak, dan air ini dapat merupakan sarana penyebaran Salmonella (WHO, 1976). Lebih lanjut Merchant dan Packer (1961) menyebutkan mikroorganisme penyebab dapat dipindahkan melalui makanan, oleh air yang tercemar secara langsung atau dengan perantara alat yang dipakai untuk mempersiapkan makanan tersebut.

Dengan adanya pencemaran tersebut tidak sesuai dengan Standar Nasional Indonesia (SNI 01-2728-1992) yang menjelaskan bahwa persyaratan yang harus dipenuhi pada uji pencemaran Salmonella pada udang putih segar per 25 gram adalah negatif. Standar tersebut mengacu pada keputusan Direktur Jenderal
Pengawasan Obat dan Makanan (POM) No. 03726/B/SK/VII/89 tanggal 10 Juli 1989 tentang batas maksimum pencemaran mikroba makanan.

Hasil uji Chi-Kuadrat menunjukkan bahwa tingkat pencemaran Salmonella sp. pada udang putih segar yang dipasarkan di pasar tradisional di wilayah Kotamadya Surabaya tidak berbeda nyata antar wilayahnya. Sehingga dapat disimpulkan bahwa pasar tradisional di wilayah Surabaya tercemar Salmonella sp.

Pencemaran Salmonella sp. tersebut dapat ditanggulangi dengan perbaikan sanitasi pasar dan lingkungan, higienis pemasaran, mencegah penanganan oleh manusia karier, serta higienis dan sanitasi lingkungan tambak dan pemasakan yang sempurna (Suryanto, 1999).

Hasil penelitian ini telah membuktikan bahwa udang putih yang dipasarkan di pasar tradisional di lima wilayah Kotamadya Surabaya tercemar oleh Salmonella sp. Oleh sebab itu perlu dilakukan tindakan yang tepat untuk menekan penyebaran Salmonellosis di Surabaya.

\section{Kesimpulan}

Udang putih segar yang dipasarkan di pasar tradisional di lima wilayah Kotamadya Surabaya tercemar Salmonella sp. tingkat pencemaran tertinggi di wilayah Surabaya Selatan (12\%) dan pencemaran terendah di wilayah Surabaya Barat dan Utara (4\%). Tingkat pencemaran Salmonella sp pada udang putih segar yang dipasarkan di pasar tradisional di lima wilayah Kotamadya Surabaya tidak menunjukkan perbedaan yang nyata $(p>0,05)$.

\section{Daftar Pustaka}

Anonimus, 1974. Prosessing of Froglegs For Export, The Marine Products Export Development Autority, Ministry of Commerce, Govt. of India. 9-10.

Anonimus, 1989. Keputusan Direktur Jenderal Obat dan Makanan Dirjen. POM, Jakarta. 274-276.

Anonimus, 1992. Meningkatkan Kualitas Krida dan Karya. Poultry Indonesia. 147.

Anonimus, 1992. Standar Nasional Indonesia Udang Segar, Jakarta. 1-3.

Buckle, K.A., Couperwhite, G.R. Davey, M.J.Eyles, G.H. Fleet, B.A. Munee, W.G. Murrel, B. Timperon, 1979. Food Borne Microorganisme of Public Health Significant. Volume I and II The Publication Unit, Registrars DivisionThe University of New South Wales. 
Darmono, 1991. Budidaya Udang Penaeus P.T. Penebar Swadaya. Jakarta.

Gray, L.D, 1995. Manual of Clinical Microbiology, $6^{\text {th }}$ ed. ASM Press. Washington, D.C. 452-453.

Holt, J.G., Krieg, N.R, Peter.H.A., Staley.T.J., Williams.S.T., 1994. Bergeys Manual of Determinatif Bacteriology, $10^{\text {th }}$ ed., Williams and Wilkins, Maryland. USA. 186.

Jawetz, E., J.L. Melnick and E.A. Adelberg, 1984. Mikrobiologi Untuk Profesi Kedokteran. Edisi 16. Penerbit Buku Kedokteran EGC. Jakarta. 214-217.

Merchant, I.A. and Packer, R.A. 1967. Veterinery Bacteriologi and Virologi. ed., lowa State Colege Press. Ames lowa. 286 - 381
Kusniyo, 1988. Salmonella dan Shigella Serta Deteksinya Dalam Bahan Pangan. Kursus Singkat Mikologi Pangan. PAU Pangan dan Gizi. Universitas Gajah Mada. Yogyakarta.

Mujiman, 1982. Budidaya Udang Windu Pusat Pembenihan Udang Probolinggo P.T. Penebar Swadaya, Anggota IKAPI, Cetakan I, Jakarta.

Prawesthirini, S. 1990. Identifikasi Salmonella Pada Udang Beku Yang Dijual Di Pasar Swalayan Surabaya. Lembaga Penelitian Universitas Airlangga. Surabaya. 1.

Suyanto, S.R. dan Mujiman, A., 1999. Budi Daya Udang Windu. Anggota IKAPI, Cetakan XII, Jakarta. 